\title{
Retraction Note to: Effect of a high fat diet on lipid absorption and fatty acid transport in a rat model of short bowel syndrome
}

\author{
Igor Sukhotnik ${ }^{1}$ A. Semih Gork ${ }^{1} \cdot$ Min Chen $^{1} \cdot$ Robert A. Drongowski $^{1} \cdot$ Arnold G. Coran $^{1} \cdot$ Carroll M. Harmon $^{1}$
}

Published online: 19 May 2021

(c) Springer-Verlag GmbH Germany, part of Springer Nature 2021

\section{Retraction Note to:}

Pediatr Surg Int (2003) 19(5):385-390

https://doi.org/10.1007/s00383-003-1016-3

The Editors-in-Chief have retracted this article because parts of Fig. 1 apparently overlap with parts of Fig. 2, and in addition parts of Fig. 1 appear to be duplicated from parts of Fig. 2 in a previously published article [1]. Author Igor Sukhotnik does not agree to this retraction. Authors A. Semih Gork, Min Chen, Robert A. Drongowski, Arnold G. Coran, and Carroll M. Harmon have not responded to any correspondence from the publisher about this retraction.

\section{Reference}

1. Sukhotnik I, May N, Gork SA et al (2002) Effect of bowel resection and high-fat diet on heart CD36/fatty-acid translocase expression in a rat model of short-bowel syndrome. Ped Surg Int 18:620 623. https://doi.org/10.1007/s00383-002-0861-9

Publisher's Note Springer Nature remains neutral with regard to jurisdictional claims in published maps and institutional affiliations.

The original article can be found online at https://doi.org/10.1007/ s00383-003-1016-3.

Igor Sukhotnik

igor-dr@internet-zahav.net

1 C.S. Mott Children's Hospital and University of Michigan Medical School, Ann Arbor, MI, USA 